\title{
Beneficial Effects of Low Frequency Vibration on Human Chondrocytes in Vitro
}

\author{
Ronald Lützenberga ${ }^{a}$ Markus Wehland ${ }^{a}$ Kendrick Solano ${ }^{a} \quad$ Mohamed Z. Nassefa \\ Christoph Buken $^{\mathrm{a}, \mathrm{b}} \quad$ Daniela Melnik ${ }^{\mathrm{a}}$ Johann Bauer ${ }^{\mathrm{c}}$ Sascha Kopp ${ }^{\mathrm{a}}$ \\ Marcus Krüger ${ }^{\mathrm{a}}$ Stefan Riwaldt ${ }^{\mathrm{a}}$ Ruth Hemmersbach ${ }^{\mathrm{d}}$ Herbert Schulz $^{\mathrm{e}}$ \\ Manfred Infanger ${ }^{a} \quad$ Daniela Grimma,b,f
}

${ }^{a}$ Clinic for Plastic, Aesthetic and Hand Surgery, Otto-von-Guericke-University Magdeburg, Magdeburg, Germany, bDepartment of Biomedicine, Aarhus University, Aarhus, Denmark, cMax-Planck Institute of Biochemistry, Martinsried, Germany, dGerman Aerospace Center, Institute of Aerospace Medicine, Gravitational Biology, Cologne, Germany, ${ }^{e}$ Cologne Center for Genomics, University of Cologne, Cologne, Germany, ${ }^{f}$ Microgravity and Translational Regenerative Medicine, Faculty of Medicine and Mechanical Engineering, Otto-von-Guericke-University Magdeburg, Magdeburg, Germany

\section{Key Words}

Vibration • Chondrocytes • Extracellular matrix • Apoptosis • Focal adhesion • Annexin A2

\begin{abstract}
Background/Aims: In articular cartilage, chondrocytes are the predominant cell type. A long-term stay in space can lead to bone loss and cartilage breakdown. Due to the poor regenerative capacity of cartilage, this may impair the crewmembers' mobility and influence mission activities. Beside microgravity other factors such as cosmic radiation and vibration might be important for cartilage degeneration. Vibration at different frequencies showed various effects on cartilage in vivo, but knowledge about its impact on chondrocytes in vitro is sparse. Methods: Human chondrocytes were exposed to a vibration device, simulating the vibration profile occurring during parabolic flights, for $24 \mathrm{~h}$ (VIB) and compared to static controls. Phase-contrast microscopy, immunofluorescence, F-actin and TUNEL staining as well as quantitative real-time PCR were performed to examine effects on morphology, cell viability and shape as well as gene expression. The results were compared to earlier studies using semantic analyses. Results: No morphological changes or cytoskeletal alterations were observed in VIB and no apoptotic cells were found. A reorganization and increase in fibronectin were detected in VIB samples by immunofluorescence technique. PXN, VCL, ANXA1, ANXA2, $B A X$, and $B C L 2$ revealed differential regulations. Conclusion: Long-term VIB did not damage human chondrocytes in vitro. The reduction of $A N X A 2$, and up-regulation of $A N X A 1, P X N$ and $V C L$ mRNAs suggest that long-term vibration might even positively influence cultured chondrocytes.

R. Lützenberg and M. Wehland contributed equally to this study.

\begin{tabular}{ll}
\hline Dr. Ronald Lützenberg & Clinic for Plastic, Aesthetic and Hand Surgery, Otto-von-Guericke-University Magdeburg, \\
and Prof. Daniela Grimm & 39120 Magdeburg (Germany); \\
& Department of Biomedicine, Aarhus University, Høegh-Guldbergsgade 10, bygn. 1116 (SKOU), \\
& 8000 Aarhus C (Denmark) \\
& Tel. +49-391-6721465, +45-87167693, E-Mail ronald.luetzenberg@med.ovgu.de; dgg@biomed.au.dk
\end{tabular}
\end{abstract}




\section{Cellular Physiology Cell Physiol Biochem 2019;53:623-637 \\ \begin{tabular}{ll|l} 
and Biochemistry & $\begin{array}{l}\text { DOI: } 10.33594 / 000000161 \\
\text { Published online: } 25 \text { September } 2019\end{array}$ & $\begin{array}{l}\text { Cell Physiol Biochem Press GmbH\&Co. KG } \\
\text { Celthor(s). Published by }\end{array}$ \\
\hline
\end{tabular} \\ Lützenberg et al.: Vibration and Chondrocytes}

\section{Introduction}

Cartilage cells, also called chondrocytes, are the sole cellular component in cartilage tissue. They synthesize extracellular matrix (ECM) proteins, such as collagen II, proteoglycans, fibronectin and others.

Several publications demonstrated that mechanical stress influences human chondrocytes in vitro and alters various biological processes such as proliferation, cell adhesion, differentiation, and signal transduction [1,2]. Human chondrocytes exposed to parabolic flight (PF) maneuvers showed an up-regulation of the cytoskeletal network genes and proteins suggesting that short-term microgravity $(\mu g)$ influences the cells to respond by reorganizing the cytoskeleton [3]. Similar data were found when human chondrocytes were investigated for $24 \mathrm{~h}$ on the random positioning machine (RPM). The chondrocytes had changed their ECM synthesis while they reorganized their cytoskeleton prior to forming three-dimensional (3D) aggregates [4, 5].

In earlier studies an effect of vibration (VIB) was observed, when chondrocytes of human origin were investigated for $2 \mathrm{~h}$ and $24 \mathrm{~h}$ with vibraplex device developed by the German Aerospace Center (Deutsches Zentrum für Luft- und Raumfahrt, DLR) [3, 6]. Short-term VIB did not negatively influence the cartilage cells [3] and also long-term VIB did not alter the morphology of human chondrocytes in vitro. No signs of apoptosis were found. However, a reduction of osteopontin protein and a decrease in PSMD4 and TBX15 gene expression suggested that VIB might have positive effects on human chondrocytes [6].

Whole-body vibration (WBV) is currently under investigation to examine whether it is an option to treat the musculoskeletal disease osteoarthritis (OA). The effects are not clarified. A recent study showed that WBV induced cartilage degeneration in mice [7], while the application of lower frequencies of WBV showed a more differentiated picture. WBV of $10 \mathrm{~Hz}$ and $20 \mathrm{~Hz}$ resulted in a reduced cartilage resorption, an increased cartilage formation, and a delayed cartilage degradation, especially when applying $20 \mathrm{~Hz}$, whereas higher frequencies of $30 \mathrm{~Hz}$ and $40 \mathrm{~Hz}$ induced worsening limb function, shrinking cartilage volume and cartilage resorption [8].

The principal aim of this study was first to address changes in the expression of selected genes of the ECM, focal adhesions and pathways of apoptosis in human chondrocytes exposed to VIB using a Vibraplex device, and secondly to compare these data with earlier $\mu g$ results from studies reporting about the effects of simulated microgravity (s- $\mu g$ ) using a Random Positioning Machine (RPM) or of real microgravity $(r-\mu g)$ achieved during PF or space missions. For this purpose, in silico analyses were performed. Moreover, the cells were examined by immunofluorescence staining and laser scanning microscopy to visualize the F-actin cytoskeleton, as well as vimentin, fibronectin and ICAM-1 proteins.

\section{Materials and Methods}

\section{Cells and Culture Medium}

Human chondrocytes from six different donors were bought from the company Provitro (Berlin, Germany). The cells were cultured in Chondrocyte Growth Medium (CGM; Provitro®, Berlin, Germany) supplemented with $10 \%$ fetal calf serum (Provitro®, Berlin, Germany) and antibiotics - 100 IU penicillin/ $\mathrm{mL}$ and $100 \mu \mathrm{g}$ streptomycin/mL (Provitro®, Berlin, Germany). Chondrocytes of passage 3 grown in T25 $\mathrm{cm}^{2}$ flasks (25 $\mathrm{cm}^{2}$; Sarstedt, Nümbrecht, Germany) were used for the experiments. The procedure was described in detail in [6].

For immunohistochemical studies, the cells were seeded in slide flasks (Thermo Fisher Scientific, Waltham, MA, USA) $24 \mathrm{~h}$ before the experiments ( $\mathrm{n}=40$ each group).

Vibration experiments

The vibration experiments were conducted as described in [3]. Briefly, the Vibraplex is a VIB platform designed and constructed by the Deutsches Zentrum für Luft- und Raumfahrt (DLR, German Center for 


\section{Cellular Physiology Cell Physiol Biochem 2019;53:623-637 \\ \begin{tabular}{ll|l} 
and Biochemistry & $\begin{array}{l}\text { DOI: 10.33594/000000161 } \\
\text { Published online: 25 September } 2019\end{array}$ & $\begin{array}{l}\text { C } 2019 \text { The Author(s). Published by } \\
\text { Cell Physiol Biochem Press GmbH\&Co. KG }\end{array}$
\end{tabular} \\ Lützenberg et al.: Vibration and Chondrocytes}

Aerospace Medicine) - Cologne, and can be used for studies to mimic the mechanical VIB encountered on an airplane during PFs.

The Vibraplex VIB platform (frequency range $0.2 \mathrm{~Hz}$ $14 \mathrm{kHz}$ ) was used to create VIB like to the ones occurring during PFs. The corresponding vibrations were recorded and analyzed by Schmidt [9]. The device is driven by an amplified wave signal equal to a $1 / \mathrm{f}^{2}$ noise (red noise), which was generated with the software WaveLab 4.0 from Steinberg. The vibration treatment of the samples during the simulated free fall phase was alleviated by about $-6 \mathrm{~dB}$. This is half of the energy found during the simulated horizontal flight. During the simulated pull-up and pullout phases, the vibrations were amplified by about $+6 \mathrm{~dB}$. The intensity of the noise applied was equivalent to $100 \mathrm{~W} / \mathrm{m}^{2}$. The Vibraplex uses $2 \mathrm{~W}$ with an experimental area of about $0.02 \mathrm{~m}^{2}$.

\section{Immunofluorescence and F-actin staining}

After the experimental procedures (VIB and static control experiments), the cell culture medium was immediately aspirated and the chondrocytes were fixed with 4\% PFA for 30 minutes at room temperature (RT). Then the slides were washed two times in DPBS. Afterwards, the slides were washed with $0.1 \%$ Triton X in DPBS for 10 min with agitation, which was followed by three more washing steps with DPBS. To prevent non-specific binding, the slides were incubated in 3\% BSA in a wet chamber for one hour. Primary antibodies diluted in $1 \%$ BSA were added to the slides overnight at $4{ }^{\circ} \mathrm{C}$ (Table 1). The following day, the slides were washed 2 times in DPBS and the secondary antibody Alexa Fluor plus 488 goat anti-mouse IgG $(\mathrm{H}+\mathrm{L})(1: 400)$ or Alexa Fluor 488 F(ab') 2 fragment of goat anti-rabbit IgG (H + L) (1:500) (both Invitrogen by Thermo Fischer Scientific) diluted in 1\% BSA was added for one hour at RT. Afterwards, the slides were washed again with DPBS and Alexa Fluor 568 phalloidin (Invitrogen by Thermo Fischer Scientific) was added for one hour, followed by three times washing with DPBS and mounting with Fluoroshield with DAPI (Sigma Life Science). Then the slides were incubated overnight at $4{ }^{\circ} \mathrm{C}$. A Carl ZEISS LSM 800 Confocal laser scanning microscope was used to examine the cells. Three lasers were used to examine the slides: $488 \mathrm{~nm}$, $561 \mathrm{~nm}$ and $405 \mathrm{~nm}$ for visualization of Alexa 488, Alexa 568 and DAPI, respectively.

\section{Viability staining}

TdT-mediated dUTP-biotin nick end labeling (TUNEL) staining was done according to the manual provided by the manufacturer (Thermo Fisher Scientific, Click-iT TUNEL Alexa Fluor 488 (cat\# C10245)). The cells for 4,6-diamidino-2-phenylindole (DAPI) staining were fixed with $3.7 \%$ formaldehyde (room temperature, $10 \mathrm{~min}$ ) and incubated in $1 \mu \mathrm{g} / \mathrm{mL}$ DAPI in PBS for $15 \mathrm{~min}$ (Invitrogen/Molecular Probes, Darmstadt, Germany). Stained cell samples (VIB and static CON) were investigated utilizing a Leica DM 2000 microscope equipped with an objective with a calibrated magnification of 400x and connected to an external light source, Leica EL 6000 (Leica Microsystems GmbH, Wetzlar, Germany). To obtain positive controls the cells were treated with DNAase before the TUNEL staining. The results were shown in the inserts of Fig. 1C, D.

\section{Microscopy}

The chondrocytes were examined with a Zeiss 510 META inverted confocal laser scanning microscope (Zeiss, Oberkochen, Germany), equipped with a Plan-Apochromat 3631.4 objective [4]. Excitation and emission wavelengths were $\lambda$ exc $=488 \mathrm{~nm}$ and $\lambda \mathrm{em}=505 \mathrm{~nm}$ for FITC.

All samples were investigated with the image analysis program Scion Image (Version 1.63 Mac 0S; Scion Corporation, Frederick, MD, USA). Phase contrast microscopy was performed using a LEICA DM2000 microscope equipped with a Leica DFC310 FX digital CCD color camera.

\section{RNA isolation and quantitative real-time PCR (qPCR)}

The RNA isolation and qPCR were performed as published earlier [6, 10]. Briefly, RNA was isolated with the RNeasy Mini Kit (Qiagen, Hilden, Germany), with an additional DNase digestion step (Qiagen) in order to eliminate residual DNA contaminations. Subsequently, the amount of RNA was quantified via a Photometer Ultrospec2010 (Amersham Biosciences, Freiburg, Germany). The first strand cDNA synthesis 


\section{Cellular Physiology and Biochemistry}

kit (Thermo Fisher Scientific, Waltham, US) was used for reverse transcription. qPCR was performed using the 7500 Fast Real-Time PCR System (Applied Biosystems, Darmstadt, Germany) according to routine protocols $[6,11]$. cDNA-selective-primers were synthesized by TIB Molbiol (Berlin, Germany) and were listed in Table 2. The primers were designed using Primer Express (Applied Biosystems, Darmstadt, Germany) to have a $\mathrm{Tm}$ of $\sim 60^{\circ} \mathrm{C}$ and to span exonexon boundaries. All samples were measured in triplicate. For normalization, 18S rRNA was used as a housekeeping gene. The comparative $\mathrm{C}_{\mathrm{T}}\left(\Delta \Delta \mathrm{C}_{\mathrm{T}}\right)$ method was used for relative quantification of transcription levels and non-vibrated controls were defined as $100 \%$ for reference.

\section{Western blot analyses}

Whole cell lysates were used for Western blotting following conventional protocols for gel electrophoresis and trans-blotting, as described earlier in [12]. Equal amounts of $10 \mu \mathrm{L}$ lysate containing $2 \mu \mathrm{g} / \mu \mathrm{L}$ protein were loaded on precast TGX stain-free gels (Bio-Rad, Munich, Germany). Transturbo blot PVDF membranes (BioRad) were used for blotting. An overview of the used antibodies and their applied concentrations is given in Table 3. The analysis was performed using ImageQuant ${ }^{\mathrm{TM}}$ LAS 4000
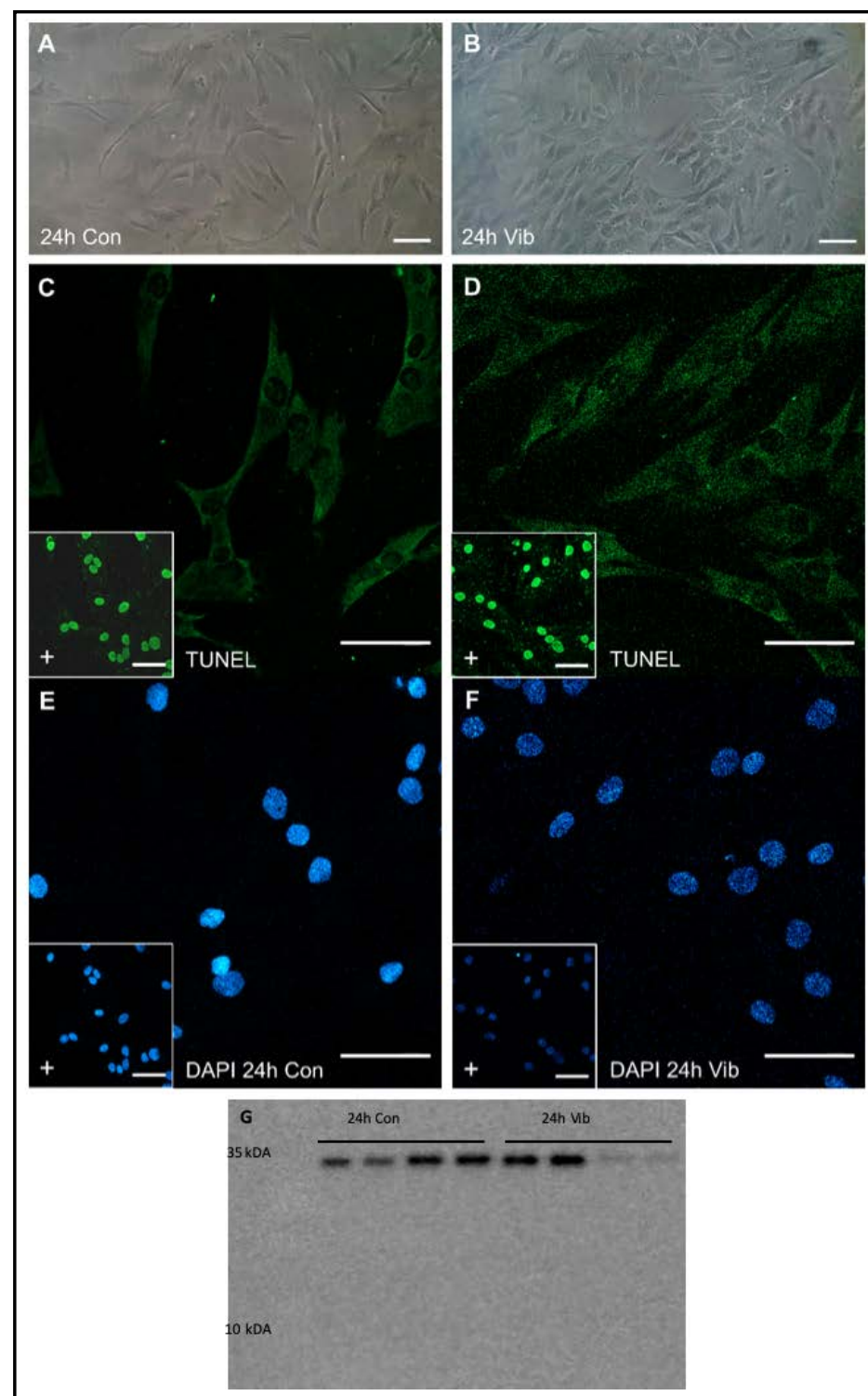

Fig. 1. Morphology of human primary chondrocytes in (A) static controls and (B) after $24 \mathrm{~h}$ of VIB. TUNEL assay in comparison to DAPI counter staining (C, D) was used for apoptosis detection (green fluorescence). Positive controls (inserts) were initiated by DNase 1 prior to staining. DAPI staining (E, F) after fixation with PFA indicated no apoptotic bodies inside the nuclei or decomposition. (G) No cleaved caspase-3 (17 kDa) could be detected by Western blot. The uncleaved Cas-3 band visible at $32 \mathrm{kDa}$. Scale bars: $100 \mu \mathrm{m}$. (GE Healthcare UK Limited, Buckinghamshire, UK), and the densitometry was performed using ImageJ (NIH).

\section{Pathway analyses}

To study the mutual regulation of genes and to visualize localization and interactions between proteins, we entered relevant UniProtKB entry numbers in the Pathway Studio v.11 software (Elsevier Research Solutions, Amsterdam, The Netherlands). The graphs were generated for the gene expression and protein regulation and binding. The method was described in earlier studies [13, 14]. STRING analyses were done with STRING 11.0, available at https://string-db.org/. 


\section{Cellular Physiology Cell Physiol Biochem 2019;53:623-637 \\ \begin{tabular}{ll|l} 
and Biochemistry & $\begin{array}{l}\text { DOI: 10.33594/000000161 } \\
\text { Published online: 25 September } 2019\end{array}$ & $\begin{array}{l}\text { C } 2019 \text { The Author(s). Published by } \\
\text { Cell Physiol Biochem Press GmbH\&Co. KG }\end{array}$
\end{tabular}}

Statistical analysis

All statistical analyses were performed using SPSS 24 software (SPSS, Inc., Chicago, IL, USA). We used the MannWhitney-U-test to assess differences, which were considered significant at the level of $p<0.05$. All data are presented as means \pm standard deviation.

\section{Results}

\section{Morphology of the chondrocytes}

After $24 \mathrm{~h}$ of VIB, no morphological differences between static control cells and vibrated chondrocytes were visible on commercially available human chondrocytes of passage 3 used for the experiments. The cells showed regular cell morphologies without any detectable alterations (Fig. 1A, B). Furthermore, all vibrated chondrocytes did not exhibit an increase in apoptosis (Fig. 1C-F). DAPI staining revealed normal nuclei in all samples (Fig. 1E, F). Positive controls given in the inserts showed apoptotic nuclei. In addition, Western blotting of cleaved caspase-3 demonstrated no activated caspase-3 (17 kDa) in all samples (Fig. 1G).

\section{The F-actin cytoskeleton, vimentin, fibronectin and} ICAM-1

Rhodamine-phalloidin staining was used to visualize the F-actin cytoskeleton after $24 \mathrm{~h}$. Both static control as well as vibrated cells displayed a normal distribution and structure of actin fibers with no signs of damage, no disarrangements or deposits of F-actin at the cellular membranes (Fig. 2A, D, G, J, $\mathrm{M}, \mathrm{P})$.

The distribution and localization of the intermediate filament vimentin was similar in both groups (Fig. 2B, E).

Significant changes in the fibronectin content of chondrocytes exposed to mechanical vibration are shown in the Fig. $2 \mathrm{H}, \mathrm{K}$. A 24-hour-exposure to vibration showed that the cells started to secrete fibronectin into the extracellular space between adjacent cells, as can clearly be seen in Fig. 2K, L. An accumulation of this ECM protein was detectable as visualized by the green fluorescein isothiocyanate fluorescence.

ICAM-1 was strongly and constantly expressed by the chondrocytes in the control and VIB group. ICAM-1 was highly accumulated around the nucleus and spread out through the cell in both the control and vibration images. No difference was detected between both groups (Fig. 2N, Q).
Table 2. Primers used for quantitative real-time PCR. All sequences are given in 5'-3'-direction

\begin{tabular}{|c|c|c|}
\hline Gene & Direction & Sequence \\
\hline \multirow[t]{2}{*}{ 18S rRNA } & forward & GGAGCCTGCGGCTTAATTT \\
\hline & reverse & CAACTAAGAACGGCCATGCA \\
\hline \multirow[t]{2}{*}{ ACAN } & forward & AGTCCAACTCTTCAAGGTGAACTA \\
\hline & reverse & ACTCAGCGAGTTGTCATGGT \\
\hline \multirow[t]{2}{*}{ ANXA1 } & forward & GCCAAAGACATAACCTCAGACACAT \\
\hline & reverse & GAATCAGCCAAGTCTTCATTCACA \\
\hline \multirow[t]{2}{*}{ ANXA2 } & forward & GGTACAAGAGTTACAGCCCTTATGACA \\
\hline & reverse & CATGGAGTCATACAGCCGATCA \\
\hline \multirow[t]{2}{*}{ BAX } & forward & GTCAGCTGCCACTCGGAAA \\
\hline & reverse & AGTAACATGGAGCTGCAGAGGAT \\
\hline \multirow[t]{2}{*}{ BCL2 } & forward & TCAGAGACAGCCAGGAGAAATCA \\
\hline & reverse & CCTGTGGATGACTGAGTACCTGAA \\
\hline \multirow[t]{2}{*}{ BIRC2 } & forward & GCTTTTGTTGTGATGGTGGCT \\
\hline & reverse & ACTCACACCTTGGAAACCACT \\
\hline \multirow[t]{2}{*}{ BIRC3 } & forward & TGCTGTGATGGTGGACTCAG \\
\hline & reverse & ACTCACACCTTGGAAACCACT \\
\hline \multirow[t]{2}{*}{ BIRC5 } & forward & GCCAGATGACGACCCCATAG \\
\hline & reverse & CACCAAGGGTTAATTCTTCAAACTG \\
\hline \multirow[t]{2}{*}{ COL1A1 } & forward & ACGAAGACATCCCACCAATCAC \\
\hline & reverse & CGTTGTCGCAGACGCAGAT \\
\hline \multirow[t]{2}{*}{ COL2A1 } & forward & GGCAATAGCAGGTTCACGTACA \\
\hline & reverse & CGATAACAGTCTTGCCCCACTT \\
\hline \multirow[t]{2}{*}{ CYC1 } & forward & CACTGCGGGAAGGTCTCTAC \\
\hline & reverse & GGGGTGCCATCGTCAAACTC \\
\hline \multirow[t]{2}{*}{ FADD } & forward & CCTGGGGAAGAAGACCTGTGTG \\
\hline & reverse & TCGATGCTGTCGATCTTGGTG \\
\hline \multirow[t]{2}{*}{ FAS } & forward & AGTCTGGTTCATCCCCATTGAC \\
\hline & reverse & AGGGATTGGAATTGAGGAAGACT \\
\hline \multirow[t]{2}{*}{ FN1 } & forward & TGAGGAGCATGGTTTTAGGAGAA \\
\hline & reverse & TCCTCATTTACATTCGGCGTATAC \\
\hline \multirow[t]{2}{*}{ NFKB1 } & forward & CTTAGGAGGGAGAGCCCAC \\
\hline & reverse & TGAAACATTTGTTCAGGCCTTC \\
\hline \multirow[t]{2}{*}{ PXN } & forward & CATGGACGACCTCGACGC \\
\hline & reverse & CAAGAACACAGGCCGTTTGG \\
\hline \multirow[t]{2}{*}{ RELA } & forward & CGCTTCTTCACACACTGGATTC \\
\hline & reverse & ACTGCCGGGATGGCTTCT \\
\hline \multirow[t]{2}{*}{ TLN1 } & forward & GATGGCTATTACTCAGTACAGACAACTGA \\
\hline & reverse & CATAGTAGACTCCTCATCTCCTTCCA \\
\hline \multirow[t]{2}{*}{ VCL } & forward & GTCTCGGCTGCTCGTATCTT \\
\hline & reverse & GTCCACCAGCCCTGTCATTT \\
\hline
\end{tabular}

Table 3. Primary antibodies for Western blotting. Ms: mouse, Rb: rabbit

\begin{tabular}{|c|c|c|c|c|}
\hline Antibodies & Company / No & Species & Detected MW (kDa) & Dilution \\
\hline Anti- $\beta$-actin & Sigma / \#A5316 & Ms & 42 & $1: 5000$ \\
\hline Anti-Caspase 3 & Cell-Signaling / \#9662S & $\mathrm{Rb}$ & $17,19,35$ & $1: 800$ \\
\hline Anti-NFkB p65 & Cell-Signaling / \#4764S & $\mathrm{Rb}$ & 65 & $1: 800$ \\
\hline
\end{tabular}




\section{Cellular Physiology \begin{tabular}{ll|l} 
and Biochemistry & Dublished online: 25 September 2019 & $\begin{array}{l}\text { C } 2019 \text { The Author(s). Published by } \\
\text { Cell Physiol Biochem Press GmbH\&Co. KG }\end{array}$
\end{tabular}}

Expression of selected genes

In order to examine the influence of VIB on cultured chondrocytes, the gene expression of selected genes belonging to biological processes such as apoptosis, extracellular matrix, cell adhesion, or focal adhesions were studied. The chosen set of 19 genes comprised ACAN, COL1A1, COL2A1, FN1 (Fig. 3), VCL, TLN1, PXN (Fig. 4), and ANXA1, ANXA2, NFKB1, RELA, BIRC2, BIRC3, BIRC5, FADD, FAS, CYC, BAX, $B C L 2$ (Fig. 5).

Significant changes were found for VCL, PXN, ANXA1, ANXA2, BAX and BCL2 mRNAs. All others were not significantly altered (Fig. 3-5). Although the gene expression of RELA was not changed after a 24-hour vibration-exposure, the NF- $\kappa \mathrm{B}$ p65 protein was down-regulated in VIB samples, which hints to the cell-protective effects of low frequency VIB on human chondrocytes in vitro (Fig. 5).

Semantic analysis of observed gene and protein alterations in combination with earlier data

As determined by qPCR the majority of the 19 genes remained unchanged after $24 \mathrm{~h}$ of treatment (Fig. 3-5). Only 6 genes (VCL, PXN, ANXA1, ANXA2, BAX and $B C L 2$ ) were significantly changed in the chondrocytes of the six donors after 24 $h$ of incubation on a Vibraplex (Fig. 3-5). In order to estimate the relevance of this data, we compared them with earlier data shown in Tables 4-6 using the Pathway Studio program.

We did not find a significant upregulation of ACAN and COL2A1 (Fig. 3). According to the pathway analysis shown in Fig. 6, which is based on a number of

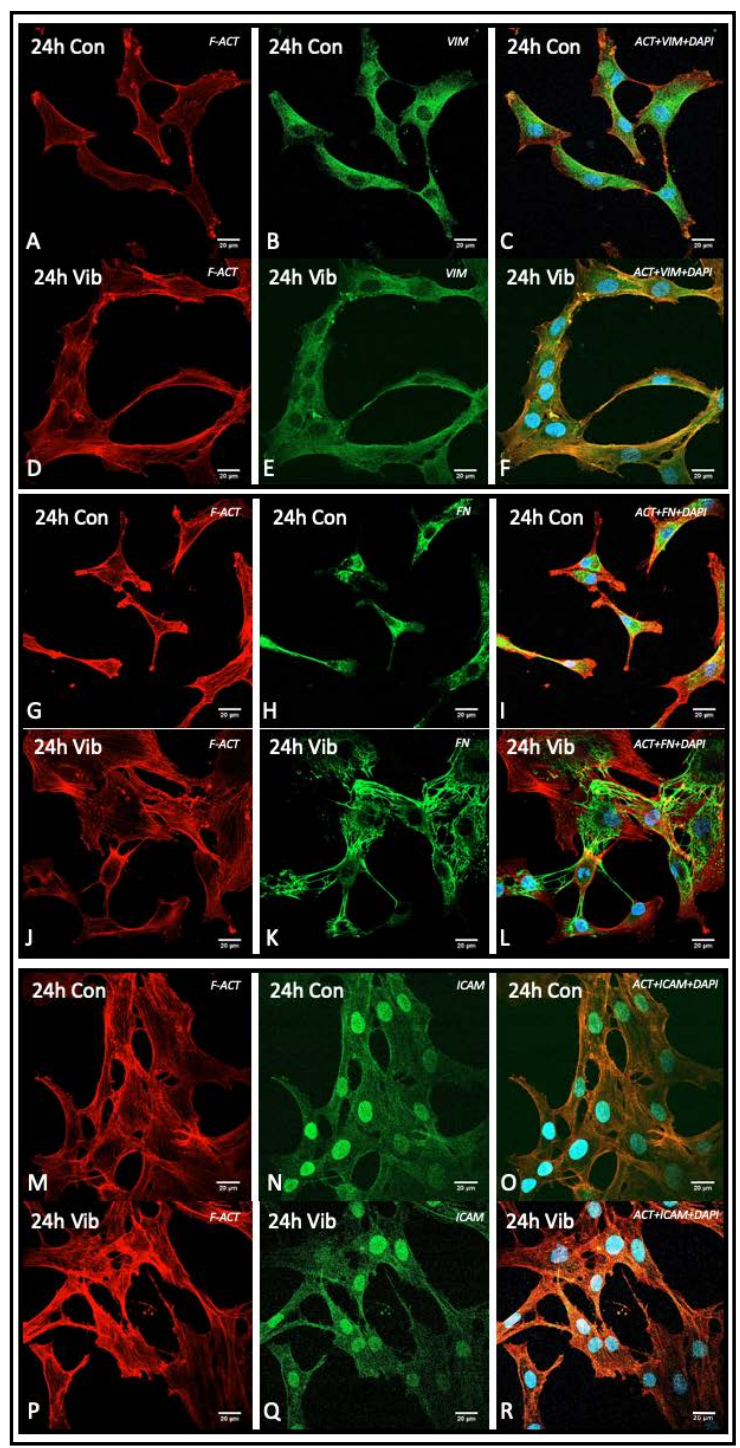

Fig. 2. Immunofluorescence staining of vimentin $(B, E)$, fibronectin $(\mathrm{H}, \mathrm{K})$ and ICAM-1 (N, Q) (green), F-actin filaments (red; A, D, G, J, M, P) and the nucleus (blue - DAPI) in chondrocytes exposed to static control conditions (A-C, G-I, M-O) or to VIB (D-F, J-L,P-R) for 24 $\mathrm{h}$. The scale bar is $20 \mu \mathrm{m}$.

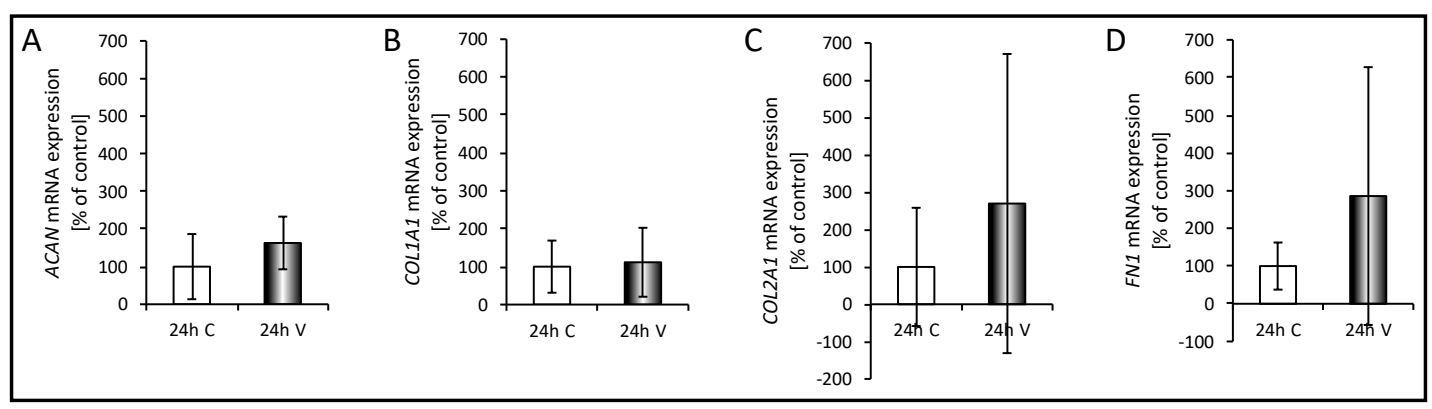

Fig. 3. Gene expression of ECM genes were determined by qPCR. Data is presented as means \pm standard deviation; $\mathrm{n}=6$ (qPCR); $\mathrm{C}=$ control; $\mathrm{V}=\mathrm{VIB}$; $^{*}=\mathrm{p}<0.05$. 
Fig. 4. Gene expression of focal adhesion genes were determined by qPCR. Data is presented as means \pm standard deviation; $\mathrm{n}=6$ (qPCR); $\mathrm{C}=$ control; $\mathrm{V}=\mathrm{VIB} ;{ }^{*}=$ $\mathrm{p}<0.05$.

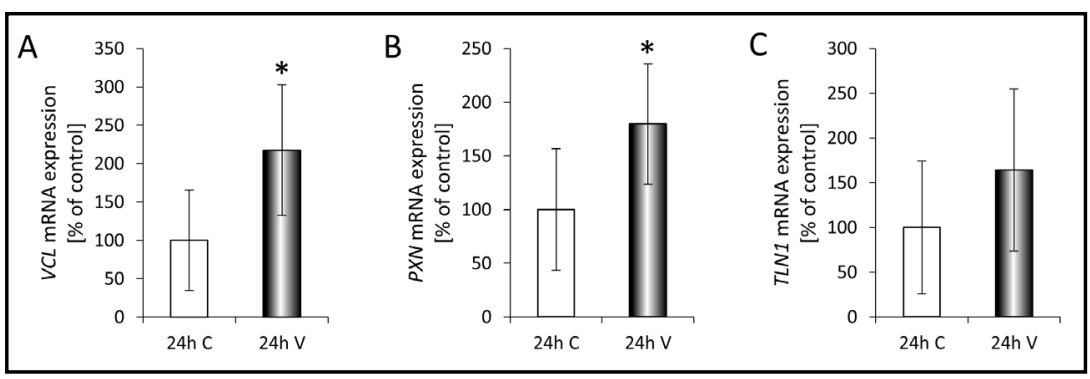

A

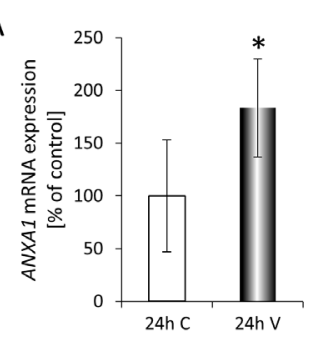

B

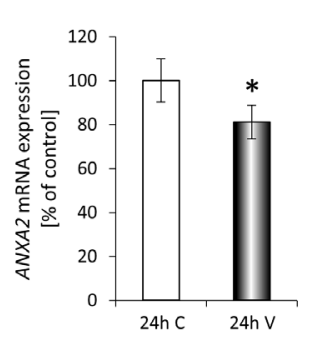

C

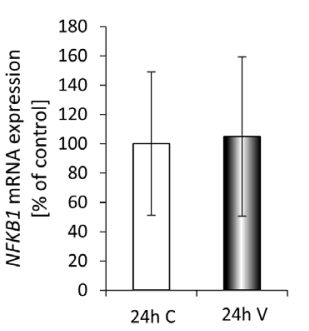

D 160

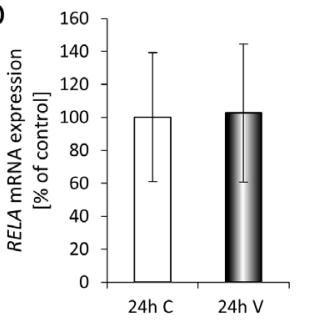

$\mathrm{E}$

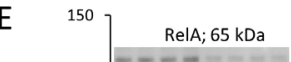

G
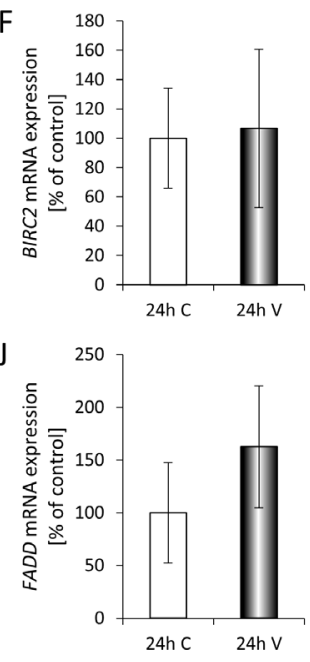

$\quad 180$
$\quad 160$

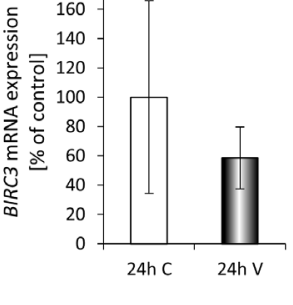

K

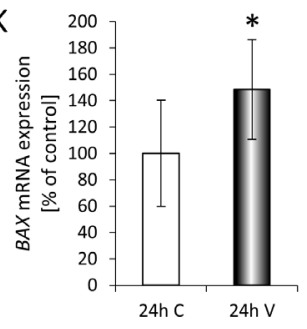

$\mathrm{H}$

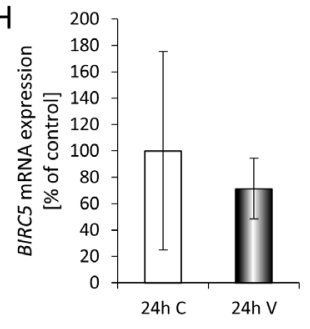

$\mathrm{L}$

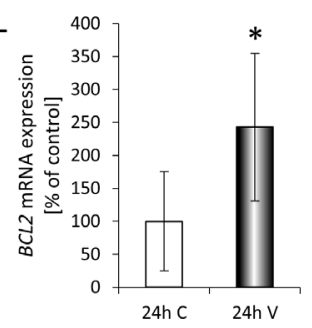

I

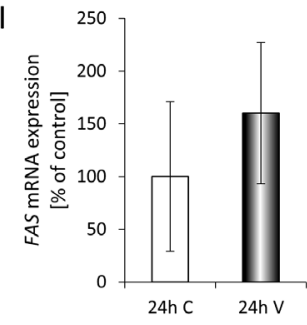

M

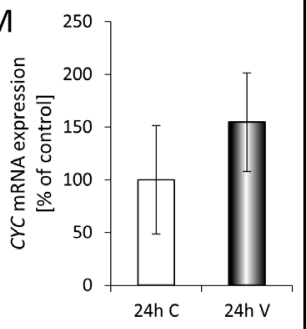

Fig. 5. Gene expression of the intrinsic and extrinsic pathway of apoptosis were determined by qPCR. In addition, the NF- $\kappa \mathrm{B}-\mathrm{p} 65$ protein content was also analyzed by Western blot. Data is presented as means \pm standard deviation; $\mathrm{n}=6$ (qPCR) and $\mathrm{n}=4$ (Western blot); $\mathrm{C}=$ control; $\mathrm{V}=\mathrm{VIB} ;{ }^{*}=\mathrm{p}<0.05$.

studies described in the literature, an up-regulation of COL2A1 may be supported by ACAN, as observed in [15] and by RELA. COL2A1 may induce an up-regulation of CXCL8 and CASP3, whereas IL6 inhibits COL2A1 expression.

According to [3], ANXA2 was down-regulated while SOX9 was up-regulated. ANXA2 inhibits CASP3 accumulation (Fig. 7). In addition, COL2A1 inhibits ACTB. Enhanced SOX5 and SOX9 transcription factors are regulating the actin cytoskeleton (Fig. 7). In Fig. 3 we demonstrate that COL2A1 was unchanged by VIB, but COL1A1 was unchanged and expressed 


\section{Cellular Physiology Cell Physiol Biochem 2019;53:623-637 \begin{tabular}{ll|l} 
and Biol: 10.33594/000000161 & C 2019 The Author(s). Published by \\
Cell Physiol Biochem Press GmbH\&Co. KG
\end{tabular}

at a low level. $A C T B$ inhibits SOX9 expression and activates $A C A N$, (Fig. 6) as it is described in [16].

In an earlier study, SPP1 was also enhanced after $31 \mathrm{P}$ at gene and at protein levels [3]. At that time $A C T B$, CAV1, ICAM1, SOX9, TUBB and VIM were up-regulated together with $S P P 1$, while SOX5 was down-regulated. This may be explained by a mutual up-regulation of SPP1, SOX9, VIM, and ICAM1 (Fig. 6, green arrows) [17-19]. SPP1 had been shown to positively influence IL6 and CXCL8 genes (Fig. 6) [20]. Wehland et al. [21] had demonstrated that the CXCL8 gene expression was up-regulated in vibrated chondrocytes and chondrocytes exposed to 31P during a PF mission (Table 5). They concluded that vibration was the major driving factor inducing the increase in CXCL8 mRNA [21].

Above, we showed that the ANXA2 mRNA was significantly down-regulated in the six donors (Fig. 5). Cleaved caspase-3 (17 kDa) was not detected in chondrocytes exposed to VIB for $24 \mathrm{~h}$ (Fig. 1G), as well as factors of the extrinsic pathway of apoptosis like FAS and FADD were not altered by vibration. Furthermore, $B A X$ and $B C L 2$ genes were both elevated and thus inhibiting each other (Fig. 8).

Furthermore, SPP1 could play an inhibitory role on $C A S P 3$ gene expression (Fig. 6, red line with cross bar) [22]. NF- $\mathrm{BB}$ p65 has an influence on aggrecan (Fig. 7). Interestingly, aggrecan and collagen type 2 were found enhanced in chondrocytes after $24 \mathrm{~h}$ on the RPM [15], but not significantly changed in VIB samples (Fig. 3), although there was a tendency to increase. In addition, after 16 days and 4 months of exposing chondrocytes to (s-) $\mu g$, collagen type II was diminished, and collagen type 1 and type 10 were reduced already after $24 \mathrm{~h}[15,23,24]$. In (s-) $\mu \mathrm{g}$, SPP1 has shown an upregulating influence on the ECM components aggrecan and collagen type 2 , but not on collagen type 1 and type 10 (Table 6) [25]. In patients suffering of $\mathrm{OA}$, osteopontin may exert a protective effect against aggrecan degradation [26]. SOX5 and SOX9 play

essential roles in producing aggrecan and collagen type 2 during cartilage formation [27-29].
Table 4. Comparison of gene and protein expression analyses with literature data from earlier experiments. $\boldsymbol{\nabla}$ : significantly down-regulated; o: no regulation; $\boldsymbol{\Delta}$ : significantly up-regulated; n.d.: not determined; n.e.: not expressed; PFC: Parabolic flight campaign; RPM: Random Positioning Machine; VIB: Vibration; 31P: after 31 parabolas

\begin{tabular}{lcccccc}
\hline & \multicolumn{3}{c}{ Gene Expression } & \multicolumn{4}{c}{ Protein Expression } \\
Gene/Protein & VIB [6] & & {$[3]$} & & {$[3]$} & {$[15]$} \\
& VIB & PFC & VIB & $1.8 \mathrm{~g}$ & PFC 31P & 24 h RPM vs. 1g \\
& vs. 1g & vs. 1g & vs. 1g & vs. 1g & vs. 1g & \\
\hline ACTB & $\circ$ & $\boldsymbol{\Delta}$ & $\circ$ & $\circ$ & $\boldsymbol{\Delta}$ & n.d. \\
ANXA2 & $\boldsymbol{\nabla}$ & n.d. & n.d. & n.d. & n.d. & n.d. \\
CASP3 & $\circ$ & n.d. & n.d. & n.d. & n.d. & $\boldsymbol{\nabla}$ \\
CAV1 & $\circ$ & $\boldsymbol{\Delta}$ & $\circ$ & $\circ$ & n.d. & n.d. \\
GAPDH & $\boldsymbol{\Delta}$ & n.d. & n.d. & n.d. & n.d. & n.d. \\
ICAM1 & $\circ$ & $\boldsymbol{\Delta}$ & $\circ$ & $\circ$ & $\boldsymbol{\Delta}$ & n.d. \\
ITGB1 & $\circ$ & n.d. & n.d. & n.d. & n.d. & n.d. \\
RELA & $\circ$ & n.d. & n.d. & n.d. & n.d. & n.d. \\
SOX5 & $\circ$ & $\boldsymbol{\nabla}$ & $\circ$ & $\circ$ & n.d. & n.d. \\
SOX9 & $\boldsymbol{\Delta}$ & $\boldsymbol{\Delta}$ & $\circ$ & $\circ$ & $\boldsymbol{\Delta}$ & n.d. \\
SPP1 & $\circ$ & $\boldsymbol{\Delta}$ & $\circ$ & $\circ$ & $\boldsymbol{\Delta}$ & n.d. \\
TUBB & $\circ$ & $\boldsymbol{\Delta}$ & $\circ$ & $\circ$ & $\boldsymbol{\Delta}$ & n.d. \\
VIM & $\circ$ & $\boldsymbol{\Delta}$ & $\circ$ & $\circ$ & $\boldsymbol{\Delta}$ & n.d. \\
\hline
\end{tabular}

Table 5. The gravitational influence on the proinflammatory cytokines IL-6 and IL-8 [21]. $\nabla$ : significantly down-regulated; o: no regulation; $\boldsymbol{\Delta}$ : significantly up-regulated; n.d.: not determined; PFC: Parabolic flight campaign; VIB: Vibration

\begin{tabular}{lcccc}
\hline \multirow{2}{*}{ Gene/Protein } & \multicolumn{2}{c}{ Gene Expression } & \multicolumn{2}{c}{ Protein Expression } \\
& $\begin{array}{c}\text { VIB } 2 \mathrm{~h} \\
\text { vs. 1g }\end{array}$ & $\begin{array}{c}\text { PFC } 2 \mathrm{~h} \\
\text { vs. 1g }\end{array}$ & $\begin{array}{c}\text { VIB } 2 \mathrm{~h} \\
\text { vs. 1g }\end{array}$ & $\begin{array}{c}1.8 \mathrm{~g} 2 \mathrm{~h} \\
\text { vs. 1g }\end{array}$ \\
\hline IL6 & $\boldsymbol{\Delta}$ & 0 & 0 & $\boldsymbol{\Delta}$ \\
CXCL8 & $\boldsymbol{\Delta}$ & $\boldsymbol{\Delta}$ & n.d. & n.d. \\
\hline
\end{tabular}

Table 6. Regulation of extracellular matrix components under altered gravity. $\mathbf{\nabla}$ : significantly down-regulated; o: no regulation; $\boldsymbol{\Delta}$ : significantly up-regulated; n.d.: not determined; PFC: Parabolic flight campaign; RPM: Random Positioning Machine; 31P: after 31 parabolas

\begin{tabular}{|c|c|c|c|c|c|}
\hline \multirow{3}{*}{ Protein/Gene } & \multicolumn{4}{|c|}{ Protein Expression } & \multirow{3}{*}{$\begin{array}{c}\text { Gene } \\
\text { Expression } \\
\text { [21] } \\
\text { PFC 31P } \\
\text { vs. 1g }\end{array}$} \\
\hline & [15] & [4] & {$[23]$} & {$[24]$} & \\
\hline & $\begin{array}{l}24 \mathrm{~h} \text { RPM } \\
\text { vs. } 1 \mathrm{~g}\end{array}$ & $\begin{array}{l}24 \mathrm{~h} \text { RPM } \\
\text { vs. } 1 \mathrm{~g}\end{array}$ & $\begin{array}{c}\text { 16d RPM/ } \\
\text { r- } \mu \mathrm{g} \\
\text { vs. } 1 \mathrm{~g}\end{array}$ & $\begin{array}{c}4 \mathrm{mo} r-\mu \mathrm{g} \\
\text { vs. } 1 \mathrm{~g}\end{array}$ & \\
\hline Aggrecan & $\boldsymbol{\Delta}$ & n.d. & $\nabla$ & n.d. & n.d. \\
\hline $\begin{array}{l}\text { Chondroitin } \\
\text { Sulfate }\end{array}$ & $\Delta$ & n.d. & n.d. & n.d. & n.d. \\
\hline Coll. Type I & $\nabla$ & n.d. & $\nabla$ & n.d. & n.d. \\
\hline Coll. Type II & $\Delta$ & $\Delta$ & $\nabla$ & $\nabla$ & $\nabla$ \\
\hline Coll. Type X & $\nabla$ & n.d. & n.d. & n.d. & n.d. \\
\hline Laminin & 0 & n.d. & n.d. & n.d. & n.d. \\
\hline
\end{tabular}


Fig. 6. Mutual interaction of genes and their products on a genetic level. The genes were selected from the studies described in Tables 4-6. The graph was generated with Pathway Studio v.11 software (Elsevier Research Solutions, Amsterdam, The Netherlands).

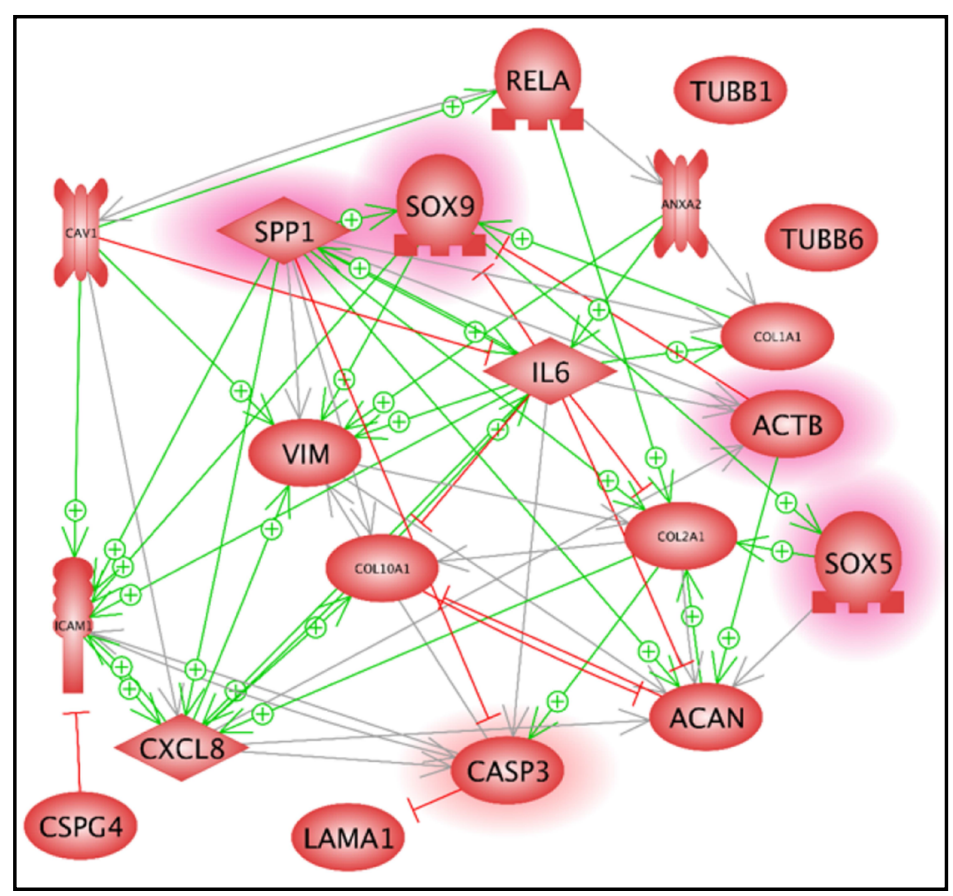

Therefore, it may be suggested that microgravity induces an up-regulation of SPP1 genes in chondrocytes and cartilage. The STRING analysis given in Fig. 8 demonstrated a central role for FN1, VCL, NFKB1, RELA, FADD and CYC1.

\section{Discussion}

In transportation systems like planes or spacecrafts one source of travelers' or crewmembers' discomfort are VIBs. They are experienced by the passengers due to the motion of the aircraft or the spacecraft in its operational mode. These VIBs can occur during normal passenger flights, but also during PF and space missions. Studies applying WBV have demonstrated an influence on bone and cartilage and propose WBV for the prevention of subchondral bone loss of knee $\mathrm{OA}$ [8]. Little is known about the direct effects of low frequency VIB on human chondrocytes, occurring during a long-term passenger flight. Therefore, we focused on the impact of low frequency VIB, measurable during a normal flight. It is known that short-term $r-\mu g$ occurring during PF maneuvers $(r-\mu g)$ for about 2 hours induced only moderate changes in human chondrocytes and a two-hour-exposure to VIB exerted no damage of the cells [5].

Cartilage tissue has a low regeneration potential. The chondrocytes show a welldifferentiated phenotype with unique physiological functions. Chondrocytes have shown to react to external stress and forces in vitro [3-6]. For example, culturing chondrocytes in simulated microgravity using $\mu g$-simulation devices like the NASA-developed rotating wall vessel (RWV) or the RPM induces three-dimensional growth of the chondrocytes and favor cartilage formation $[30,31]$.

However, long-term space missions revealed bone loss and cartilage breakdown in crewmembers, resulting in similar symptoms compared to OA [32, 33]. Therefore, it is of high interest to design and perform new studies focusing on chondrocytes in vitro or cartilage in vivo. Recently, a paper demonstrated the effects of low-magnitude WBV on cartilage degradation, bone/cartilage turnover, and $\mathrm{OA}$ joint function in a rabbit knee $\mathrm{OA}$ model $[33,34]$. Lower frequency $(20 \mathrm{~Hz}) \mathrm{WBV}$ revealed beneficial effects for the bone micro-structure [34]. 
Fig. 7. Mutual interaction of proteins, which were selected from the studies described in the Tables 4-6. The graph was generated with Pathway Studio v.11 software (Elsevier Research Solutions, Amsterdam, The Netherlands).

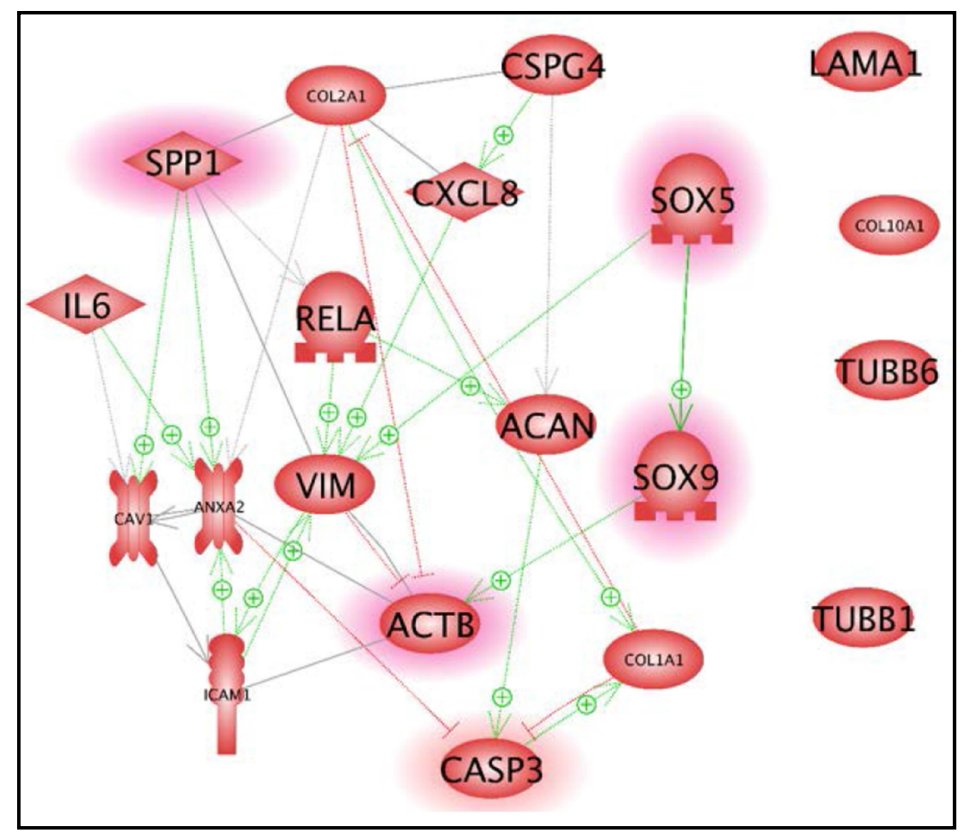

We used human chondrocytes deriving from six different donors. The cells were exposed to the Vibraplex device in vitro. We did not detect any VIB-induced morphological changes and no cell death, which confirmed earlier data [6]. Recently, we had performed a whole genome microarray analysis on vibrated chondrocytes. Overall, we detected that VIB had only very little influence on the differential gene expression in chondrocytes [6].

In this study, we focused on selected genes belonging to the extracellular matrix which are characteristic for chondrocytes (ACAN, COL2A1), on focal adhesion markers and on factors of the intrinsic and extrinsic pathway of apoptosis. The objective was to further verify our hypothesis that VIB might have beneficial effects on chondrocytes and eventually on cartilage.

Long-term VIB of human chondrocytes in vitro promotes the interaction of cells leading to changes in extracellular matrix proteins or cell adhesion molecules such as fibronectin. Fibronectin was disorganized and accumulated in the extracellular space in vibrated chondrocytes compared to control cells (Fig. 2). Fibronectin is a key factor of the osteoarthritic process and it plays a central role in this study as demonstrated by the interaction network shown in Fig. 8. In particular, in the early stages of OA fibronectin has shown a rapid accumulation of the ECM, which might suggest an attempt of the tissue to repair itself [34]. A large elevation of FN1 and SPP1 mRNAs was measured in human OAaffected cartilage samples as compared with normal cartilage [35, 36]. Both cell adhesion molecules are involved in the inflammatory process of $\mathrm{OA}$.

$S P P 1$ was not significantly altered by vibration which hints to a more beneficial effect [6, 35], as an elevated osteopontin content could be involved in cartilage damage in astronauts, where osteopontin is linked to severity and progression of OA. Studies have shown that OA patients present higher concentrations of osteopontin as compared to healthy patients $[3,4$, $8,26,37,38]$.

We investigated whether focal adhesion genes are influenced by vibration in chondrocytes (Fig. 3-5). Focal adhesion proteins link the ECM and the actin cytoskeleton. They propagate signals arising from the activation of integrins following their engagement with ECM proteins like fibronectin. Fibronectin binding by cells influences vinculin (Fig. 8). Vibration significantly elevated the VCL mRNA expression. A fibronectin-vinculin transmembrane interaction is involved in differentiation processes [39].

Midpalatal suture cartilage cells exposed to expansive stimulation form actin stress fibers, and a reorganization of focal adhesion contacts (vinculin) occurred [40]. In parallel, 


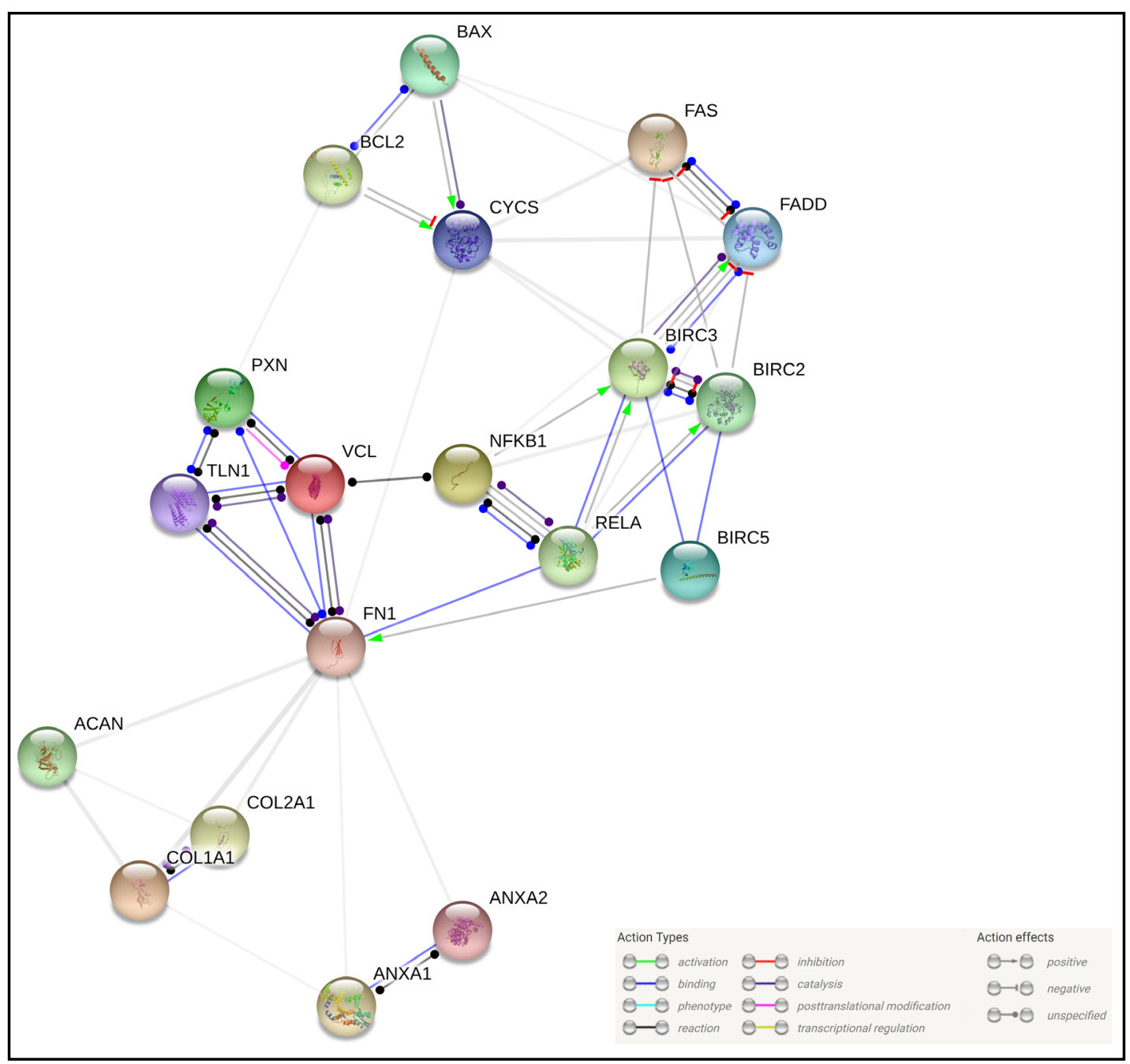

Fig. 8. STRING analysis with the major protein-protein interactions for chondrocytes experiments under mechanical vibration. The visualization was made using the online software STRING [https://string-db. $\operatorname{org} /]$.

fibronectin was elevated [39], which is comparable to our in vitro findings. Vibration also elevated the PXN mRNA in human chondrocytes (Fig. 4). The association of focal adhesion kinase with fibronectin and paxillin is required for precartilage condensation of chick mesenchymal cells [41]. Paxillin serves as a critical transducer of signals from fibronectin [42]. Vinculin has shown to regulate the survival of mouse embryonal cancer cells through regulating paxillin-FAK interactions to alter ERK1/2 activation [43]. In addition, paxillin is acting anti-apoptotic and is involved in the survival of mouse cells [44].

We have focused on apoptosis applying TUNEL staining. In all cultures of the six donors no morphological signs of programmed cell death were detectable. The CASP3 and RELA gene expression was not significantly changed, but a significant reduction of the ANXA2 gene expression was found in vibrated chondrocytes after $24 \mathrm{~h}$. Cleaved caspase- 3 protein $(17 \mathrm{kDa})$ was not detectable. As the chondrocytes are the only cell type found in cartilage, inhibition of programmed cell death may be crucial for the maintenance of healthy cartilage [45]. The protein of $A N X A 2$ is annexin-A2, which is belonging to the annexin family. It plays a role in the development of OA. Annexin-A2 is involved in regulating cellular growth, cell motility and in signal transduction pathways (extracellular matrix). Human osteoarthritic chondrocytes undergo terminal differentiation, and are releasing, among other factors, 


\section{Cellular Physiology Cell Physiol Biochem 2019;53:623-637 \\ \begin{tabular}{ll|l} 
and Biochemistry & $\begin{array}{l}\text { DOl: 10.33594/000000161 } \\
\text { Published online: 25 September } 2019\end{array}$ & $\begin{array}{l}\text { O } 2019 \text { The Author(s). Published by } \\
\text { Cell Physiol Biochem Press GmbH\&Co. KG }\end{array}$ \\
\cline { 2 - 3 }
\end{tabular} \\ Lützenberg et al.: Vibration and Chondrocytes}

annexinA II-containing matrix vesicles which are able to initiate mineral formation, and ultimately die by apoptosis. Thus, these cells are involved in the destruction of articular cartilage in OA [46]. Moreover, we detected an up-regulation of ANXA1 mRNA after vibration. ANXA1 inhibits the activation of NF- $\kappa B$ (nuclear factor $\kappa$-light-chain-enhancer of activated $B$ cells) by binding to the p65 subunit [47], it is anti-proliferative, anti-apoptotic and associated with survival in gastric cancer [48].

In this study the gene expression of RELA was not changed after a 24-hour vibrationexposure, but the NF- $\kappa B$ p65 protein was down-regulated in VIB samples, which hints to the cell-protective effects of low frequency VIB on human chondrocytes in vitro. In addition, we studied key factors of the intrinsic and extrinsic pathway of programmed cell death. $B A X$ (Bcl-2 associated X-protein) and BCL2 mRNAs were significantly up-regulated, whereas CYC1 was not changed. In addition, $F A S$ and $F A D D$ were not changed by vibration. In a next step, we investigated the $B I R C 2, B I R C 3, B I R C 5$, which are members of the protein (IAP) family. IAPs are regulating the caspase activity, as well as proliferation and survival. None of these genes were changed in expression, neither BIRC2, which is the gene of the Baculoviral IAP repeatcontaining protein 2, nor BIRC3, which inhibit apoptosis by binding to the tumor necrosis factor receptor-associated factors TRAF1 and TRAF2. BIRC2 inhibits the activation of caspases-3, -7 and -9 [49]. BIRC5 gene is coding for the surviving factor was also not changed by vibration. Hence, we did not find signs that vibration for $24 \mathrm{~h}$ modulates chondrocyte apoptosis.

These experiments demonstrated that long-term VIB showed beneficial effects. The up-regulation of $V C L, P X N, A N X A 1$ and the down-regulation of ANXA2 seem to protect the chondrocytes and inhibits dedifferentiation.

\section{Conclusion}

In conclusion, a 24-hour exposure to vibration as generated by the Vibraplex showed beneficial effects on human chondrocytes which did not reveal any noteworthy morphological alterations or damage. Pathway analyses hint towards a beneficial influence of this kind of vibration on human cartilage cells. The future of space exploration will involve long-duration spaceflights and stays on the International Space Station or flights to the Mars and beyond, and crewmembers will be subjected to a number of stressors like microgravity, vibration or cosmic radiation. Therefore, long-term vibration and microgravity studies on different cell types like endothelial cells [50] or lymphocytes [51] should be performed in the future.

\section{Abbreviations}

$\mu g$ (Microgravity); 3D (Three dimensional); ACAN (Aggrecan); ACTB (Beta-actin); ANXA1 (Annexin a1); ANXA2 (Annexin a2); BAX (Apoptosis regulator BAX); BCL2 (Apoptosis regulator BCL2); BIRC2 (Baculoviral IAP repeat-containing protein 2); BIRC3 (Baculoviral IAP repeat-containing protein 3); BIRC5 (Baculoviral IAP repeat-containing protein 5); BSA (Bovine serum albumin); CASP3 (Caspase-3); COL1A1 (Collagen alpha-1(I) chain); COL2A1 (Collagen alpha-1(II) chain); CON (Control); CXCL8 (Interleukin-8); CYC1 (Cytochrome c1); DAPI (4',6-diamidino-2-phenylindole); DLR (Deutsches Zentrum für Luft- und Raumfahrt); DPBS (Dulbeccos phosphate buffered saline); ECM (Extracellular matrix); ERK1/2 (Mitogenactivated protein kinase 3/6); FADD (FAS-associated death domain protein); FAS (Tumor necrosis factor receptor superfamily member 6); FITC (Fluorescein isothiocyanate); FN1 (Fibronectin 1); IAP (Inhibitor of apoptosis protein); ICAM-1 (Intercellular adhesion molecule 1); IL6 (Interleukin-6); NF-KB p65 (Nuclear factor NF-kappa-B p65 subunit); NFKB1 (Nuclear factor NF-kappa-B p105 subunit); OA (Osteoarthritis); PCR (Polymerase chain reaction); PF (Parabolic flight); PSMD4 (26S proteasome non-ATPase regulatory subunit 4); PVDF (Polyvinylidine fluoride); PXN (Paxillin); r- $\mu g$ (real microgravity); RELA 


\section{Cellular Physiology Cell Physiol Biochem 2019;53:623-637 \begin{tabular}{ll|l} 
and Biochemistry & $\begin{array}{l}\text { DOl: 10.33594/000000161 } \\
\text { Published online: } 25 \text { September } 2019\end{array}$ & $\begin{array}{l}\text { C 2019 The Author(s). Published by } \\
\text { Cell Physiol Biochem Press GmbH\&Co. KG }\end{array}$ \\
\cline { 2 - 3 }
\end{tabular} \\ Lützenberg et al.: Vibration and Chondrocytes}

(Nuclear factor NF-kappa-B p65 subunit); RPM (Random positioning machine); RWV (Rotating wall vessel); $s-\mu g$ (simulated microgravity); SOX5 (Transcription factor SOX-5); SOX9 (Transcription factor SOX-9); SPP1 (Osteopontin); TBX15 (T-box transcription factor TBX15); TRAF 1/2 (TNF receptor-associated factor 1/2); TUBB (Beta-tubulin); TUNEL (TdTmediated dUTP-biotin nick end labeling); VCL (Vinculin); VIB (Vibration); VIM (Vimentin); WBV (Whole body vibration).

\section{Acknowledgements}

The authors like to thank the European Space Agency (ESA; (DG, RH) ESA-CORA-GBFProject 2014-03 "Vibrated Chondrocytes"), the German Space Agency (DLR; (DG) BMWi projects 50WB1524 and 50WB1924), and Aarhus University, Denmark, for funding of this study.

The views expressed herein can in no way be taken to reflect the official opinion of the German Space Agency and the European Space Agency.

\section{Disclosure Statement}

The authors declare no competing financial interests.

\section{References}

1 Chen CS, Ingber DE: Tensegrity and mechanoregulation: From skeleton to cytoskeleton. Osteoarthritis Cartilage 1999;7:81-94.

2 Davisson T, Sah RL, Ratcliffe A: Perfusion increases cell content and matrix synthesis in chondrocyte threedimensional cultures. Tissue Eng 2002;8:807-816.

3 Aleshcheva G, Wehland M, Sahana J, Bauer J, Corydon TJ, Hemmersbach R, Frett T, Egli M, Infanger M, Grosse J, Grimm D: Moderate alterations of the cytoskeleton in human chondrocytes after short-term microgravity produced by parabolic flight maneuvers could be prevented by up-regulation of bmp-2 and sox-9. FASEB J 2015;29:2303-2314.

4 Aleshcheva G, Sahana J, Ma X, Hauslage J, Hemmersbach R, Egli M, Infanger M, Bauer J, Grimm D: Changes in morphology, gene expression and protein content in chondrocytes cultured on a random positioning machine. PLoS One 2013;8:e79057.

5 Aleshcheva G, Bauer J, Hemmersbach R, Egli M, Wehland M, Grimm D: Tissue engineering of cartilage on ground-based facilities. Microgravity Sci Technol 2016;28:237-245.

6 Lützenberg R, Solano K, Buken C, Sahana J, Riwaldt S, Kopp S, Krüger M, Schulz H, Saar K, Huebner N, Hemmersbach R, Bauer J, Infanger M, Grimm D, Wehland M: Pathway analysis hints towards beneficial effects of long-term vibration on human chondrocytes. Cell Physiol Biochem 2018;47:1729-1741.

7 McCann MR, Yeung C, Pest MA, Ratneswaran A, Pollmann SI, Holdsworth DW, Beier F, Dixon SJ, Seguin CA: Whole-body vibration of mice induces articular cartilage degeneration with minimal changes in subchondral bone. Osteoarthritis Cartilage 2017;25:770-778.

8 Junbo W, Sijia L, Hongying C, Lei L, Pu W: Effect of low-magnitude different-frequency whole-body vibration on subchondral trabecular bone microarchitecture, cartilage degradation, bone/cartilage turnover, and joint pain in rabbits with knee osteoarthritis. BMC Musculoskelet Disord 2017;18:260.

9 Schmidt W. Quickly changing acceleration forces (QCAFs) vibration analysis on the A300 ZERO-G. Microgravity Sci Technol 2004;15:42-48.

10 Dittrich A, Grimm D, Sahana J, Bauer J, Krüger M, Infanger M, Magnusson NE: Key proteins involved in spheroid formation and angiogenesis in endothelial cells after long-term exposure to simulated microgravity. Cell Physiol Biochem 2018;45:429-445. 


\section{Cellular Physiology Cell Physiol Biochem 2019;53:623-637 \begin{tabular}{ll|l} 
and Biol: $10.33594 / 000000161$ & & C 2019 The Author(s). Published by
\end{tabular} and BIOChemistry Published online: 25 September 2019 Cell Physiol Biochem Press GmbH\&Co. KG \\ Lützenberg et al.: Vibration and Chondrocytes}

11 Pietsch J, Gass S, Nebuloni S, Echegoyen D, Riwaldt S, Baake C, Bauer J, Corydon TJ, Egli M, Infanger M, Grimm D: Three-dimensional growth of human endothelial cells in an automated cell culture experiment container during the spacex crs-8 iss space mission - the spheroids project. Biomaterials 2017;124:126156.

12 Riwaldt S, Monici M, Graver Petersen A, Birk Jensen U, Evert K, Pantalone D, Utpatel K, Evert M, Wehland M, Krüger M, Kopp S, Frandsen S, Corydon T, Sahana J, Bauer J, Lützenberg R, Infanger M, Grimm D: Preparation of a spaceflight: Apoptosis search in sutured wound healing models. Int J Mol Sci 2017;18:pii:E2604.

13 Riwaldt S, Bauer J, Wehland M, Slumstrup L, Kopp S, Warnke E, Dittrich A, Magnusson NE, Pietsch J, Corydon TJ, Infanger M, Grimm D: Pathways regulating spheroid formation of human follicular thyroid cancer cells under simulated microgravity conditions: A genetic approach. Int J Mol Sci 2016;17:528.

14 Bauer J, Kopp S, Schlagberger EM, Grosse J, Sahana J, Riwaldt S, Wehland M, Luetzenberg R, Infanger M, Grimm D: Proteome analysis of human follicular thyroid cancer cells exposed to the random positioning machine. Int J Mol Sci 2017;18:pii:E546.

15 Ulbrich C, Westphal K, Pietsch J, Winkler HD, Leder A, Bauer J, Kossmehl P, Grosse J, Schoenberger J, Infanger M, Egli M, Grimm D: Characterization of human chondrocytes exposed to simulated microgravity. Cell Physiol Biochem 2010;25:551-560.

16 Akiyama H, Chaboissier MC, Martin JF, Schedl A, de Crombrugghe B: The transcription factor sox9 has essential roles in successive steps of the chondrocyte differentiation pathway and is required for expression of sox5 and sox6. Genes Dev 2002;16:2813-2828.

17 Kawai T, Yasuchika K, Ishii T, Miyauchi Y, Kojima H, Yamaoka R, Katayama H, Yoshitoshi EY, Ogiso S, Kita S, Yasuda K, Fukumitsu K, Komori J, Hatano E, Kawaguchi Y, Uemoto S: Sox9 is a novel cancer stem cell marker surrogated by osteopontin in human hepatocellular carcinoma. Sci Rep 2016;6:30489.

18 Ahmed M, Kundu GC: Osteopontin selectively regulates p70s6k/mtor phosphorylation leading to nf-kappab dependent ap-1-mediated icam-1 expression in breast cancer cells. Mol Cancer 2010;9:101.

19 Matsushima H, Kuroki T, Kitasato A, Adachi T, Tanaka T, Hirabaru M, Hirayama T, Kuroshima N, Hidaka M, Soyama A, Takatsuki M, Kinoshita N, Sano K, Nishida N, Eguchi S: Sox9 expression in carcinogenesis and its clinical significance in intrahepatic cholangiocarcinoma. Dig Liver Dis 2015;47:1067-1075.

20 Yang Y, Gao SG, Zhang FJ, Luo W, Xue JX, Lei GH: Effects of osteopontin on the expression of il-6 and il-8 inflammatory factors in human knee osteoarthritis chondrocytes. Eur Rev Med Pharmacol Sci 2014;18:3580-3586.

21 Wehland M, Aleshcheva G, Schulz H, Saar K, Hübner N, Hemmersbach R, Braun M, Ma X, Frett T, Warnke E, Riwaldt S, Pietsch J, Corydon TJ, Infanger M, Grimm D: Differential gene expression of human chondrocytes cultured under short-term altered gravity conditions during parabolic flight maneuvers. Cell Commun Signal 2015;13:18.

22 Zhao H, Chen Q, Alam A, Cui J, Suen KC, Soo AP, Eguchi S, Gu J, Ma D: The role of osteopontin in the progression of solid organ tumour. Cell Death Dis 2018;9:356.

23 Stamenkovic V, Keller G, Nesic D, Cogoli A, Grogan SP: Neocartilage formation in $1 \mathrm{~g}$, simulated, and microgravity environments: Implications for tissue engineering. Tissue Eng Part A 2010;16:1729-1736.

24 Freed LE, Langer R, Martin I, Pellis NR, Vunjak-Novakovic G: Tissue engineering of cartilage in space. Proc Natl Acad Sci U S A 1997;94:13885-13890.

25 Grogan SP, Chen X, Sovani S, Taniguchi N, Colwell CW, Jr., Lotz MK, D’Lima DD: Influence of cartilage extracellular matrix molecules on cell phenotype and neocartilage formation. Tissue Eng Part A 2014;20:264-274.

26 Gao SG, Zeng C, Song Y, Tian J, Cheng C, Yang T, Li H, Zhang FJ, Lei GH: Effect of osteopontin on the mrna expression of adamts 4 and adamts5 in chondrocytes from patients with knee osteoarthritis. Exp Ther Med 2015;9:1979-1983.

27 Lefebvre V, Dvir-Ginzberg M: Sox9 and the many facets of its regulation in the chondrocyte lineage. Connect Tissue Res 2017;58:2-14.

28 Lefebvre V, Behringer RR, de Crombrugghe B: L-sox5, sox6 and sox9 control essential steps of the chondrocyte differentiation pathway. Osteoarthritis Cartilage 2001;9:S69-75.

29 Han Y, Lefebvre V: L-sox5 and sox6 drive expression of the aggrecan gene in cartilage by securing binding of sox9 to a far-upstream enhancer. Mol Cell Biol 2008;28:4999-5013. 


\section{Cellular Physiology Cell Physiol Biochem 2019;53:623-637 \begin{tabular}{ll|l} 
and Biochemistry & $\begin{array}{l}\text { DOl: 10.33594/000000161 } \\
\text { Published online: 25 September } 2019\end{array}$ & $\begin{array}{l}\text { O } 2019 \text { The Author(s). Published by } \\
\text { Cell Physiol Biochem Press GmbH\&Co. KG }\end{array}$ \\
\cline { 2 - 3 }
\end{tabular} \\ Lützenberg et al.: Vibration and Chondrocytes}

30 Grimm D, Egli M, Krüger M, Riwaldt S, Corydon TJ, Kopp S, Wehland M, Wise P, Infanger M, Mann V, Sundaresan A: Tissue engineering under microgravity conditions-use of stem cells and specialized cells. Stem Cells Dev 2018;27:787-804.

31 Ulbrich C, Wehland M, Pietsch J, Aleshcheva G, Wise P, van Loon J, Magnusson N, Infanger M, Grosse J, Eilles C, Sundaresan A, Grimm D: The impact of simulated and real microgravity on bone cells and mesenchymal stem cells. Biomed Res Int 2014;2014:928507.

32 Grimm D, Grosse J, Wehland M, Mann V, Reseland JE, Sundaresan A, Corydon TJ: The impact of microgravity on bone in humans. Bone 2016;87:44-56.

33 Sanchez-Adams J, Leddy HA, McNulty AL, O'Conor CJ, Guilak F: The mechanobiology of articular cartilage: Bearing the burden of osteoarthritis. Curr Rheumatol Rep 2014;16:451.

34 Wang JB, Liu SJ, Chen HY, Wang P: [effects of low-magnitude whole body vibration (wbv) on knee osteoarthritis in rabbits]. Sichuan Da Xue Xue Bao Yi Xue Ban 2017;48:537-542.

35 Chevalier X: Fibronectin, cartilage, and osteoarthritis. Semin Arthritis Rheum 1993;22:307-318.

36 Attur MG, Dave MN, Stuchin S, Kowalski AJ, Steiner G, Abramson SB, Denhardt DT, Amin AR: Osteopontin: An intrinsic inhibitor of inflammation in cartilage. Arthritis Rheum 2001;44:578-584.

37 Gravallese EM: Osteopontin: A bridge between bone and the immune system. J Clin Invest 2003;112:147149.

38 Li Y, Jiang W, Wang H, Deng Z, Zeng C, Tu M, Li L, Xiao W, Gao S, Luo W, Lei G: Osteopontin promotes expression of matrix metalloproteinase 13 through nf-kappab signaling in osteoarthritis. Biomed Res Int 2016;2016:6345656.

39 Lesot H, Kubler MD, Fausser JL, Ruch JV: A 165 kda membrane antigen mediating fibronectin-vinculin interaction is involved in murine odontoblast differentiation. Differentiation 1990;44:25-35.

40 Takahashi I, Onodera K, Sasano Y, Mizoguchi I, Bae JW, Mitani H, Kagayama M, Mitani H: Effect of stretching on gene expression of beta1 integrin and focal adhesion kinase and on chondrogenesis through cellextracellular matrix interactions. Eur J Cell Biol 2003;82:182-192.

41 Bang OS, Kim EJ, Chung JG, Lee SR, Park TK, Kang SS: Association of focal adhesion kinase with fibronectin and paxillin is required for precartilage condensation of chick mesenchymal cells. Biochem Biophys Res Commun 2000;278:522-529.

42 Li D, Ding J, Wang X, Wang C, Wu T: Fibronectin promotes tyrosine phosphorylation of paxillin and cell invasiveness in the gastric cancer cell line ags. Tumori 2009;95:769-779.

43 Subauste MC, Pertz O, Adamson ED, Turner CE, Junger S, Hahn KM: Vinculin modulation of paxillin-fak interactions regulates erk to control survival and motility. J Cell Biol 2004;165:371-381.

44 Nah AS, Chay KO: Roles of paxillin phosphorylation in il-3 withdrawal-induced ba/f3 cell apoptosis. Genes Genomics 2019;41:241-248.

45 Matsuo M, Nishida K, Yoshida A, Murakami T, Inoue H: Expression of caspase-3 and -9 relevant to cartilage destruction and chondrocyte apoptosis in human osteoarthritic cartilage. Acta Med Okayama 2001;55:333340.

46 Kirsch T, Swoboda B, Nah H: Activation of annexin ii and v expression, terminal differentiation, mineralization and apoptosis in human osteoarthritic cartilage. Osteoarthritis Cartilage 2000;8:294-302.

47 Zhang Z, Huang L, Zhao W, Rigas B: Annexin 1 induced by anti-inflammatory drugs binds to nf-kappab and inhibits its activation: Anticancer effects in vitro and in vivo. Cancer Res 2010;70:2379-2388.

48 Cheng TY, Wu MS, Lin JT, Lin MT, Shun CT, Huang HY, Hua KT, Kuo ML: Annexin a1 is associated with gastric cancer survival and promotes gastric cancer cell invasiveness through the formyl peptide receptor/ extracellular signal-regulated kinase/integrin beta-1-binding protein 1 pathway. Cancer 2012;118:57575767.

49 Saleem M, Qadir MI, Perveen N, Ahmad B, Saleem U, Irshad T, Ahmad B: Inhibitors of apoptotic proteins: New targets for anticancer therapy. Chem Biol Drug Des 2013;82:243-251.

50 Krüger M, Pietsch J, Bauer J, Kopp S, Carvalho DTO, Baatout S, Moreels M, Melnik D, Wehland M, Egli M, Jayashree S, Kobbero SD, Corydon TJ, Nebuloni S, Gass S, Evert M, Infanger M, Grimm D: Growth of endothelial cells in space and in simulated microgravity - a comparison on the secretory level. Cell Physiol Biochem 2019;52:1039-1060.

51 Battista N, Meloni MA, Bari M, Mastrangelo N, Galleri G, Rapino C, Dainese E, Agro AF, Pippia P, Maccarrone M: 5-lipoxygenase-dependent apoptosis of human lymphocytes in the international space station: Data from the roald experiment. FASEB J 2012;26:1791-1798. 